\title{
Chilling privation during dormancy period and carbohydrate mobilization in Japanese pear trees
}

\author{
Anderson Carlos Marafon ${ }^{1 *}$, Idemir Citadin ${ }^{2}$, Luciano do Amarante ${ }^{3}$, Flávio Gilberto Herter ${ }^{4}$, \\ Fernando José Hawerroth ${ }^{5}$ \\ ${ }^{1}$ Embrapa Tabuleiros Costeiros - Unidade de Execução de Pesquisa de Rio Largo, Rod. Br 104, km 85, Campus \\ Delza Gitai, 57100-000 - Rio Largo, AL - Brasil. \\ ${ }^{2} U T F P r$, Via do Conbecimento, km 01, C.P. 571 - 85501-970 - Pato Branco, PR - Brasil. \\ ${ }^{3}$ UFPel - Instituto de Química e Geociências, Campus Universitário, C.P. 354 - 96010-900 - Pelotas, RS - Brasil. \\ ${ }^{4}$ UFPel/Faculdade de Agronomia Eliseu Maciel - Depto. de Fitotecnia, Campus Universitário, C.P. 354 - \\ 96010-900 - Pelotas, RS - Brasil. \\ 'Embrapa Agroindústria Tropical - R. Doutora Sara Mesquita, 2270, Planalto do Pici - 60511-110 - Fortaleza, \\ CE - Brasil. \\ *Corresponding Author < anderson.marafon@gmail.com> \\ Edited by: Leonardo Oliveira Medici
}

\begin{abstract}
The flower bud abortion is one of the main problems that limit commercial pear (Pyruspyrifolia) production in the southern region of Brazil. Insufficient chilling during the dormancy period is known as the main factor of this problem. One of the hypotheses to explain this problem is that the starch mobilization and carbohydrate fluxes to the buds are impeded when mild temperatures occurred during winter. This study compared the total soluble sugars (TSS) and reducing sugars (RS) concentrations, the cell wall acid invertase (CWAI - EC 3.2.1.26) and sucrose-phosphate synthase (SPS - EC 2.4.1.14) activities in wood of branches and floral buds of Japanese pear trees cv. Housui, grafted on Pyrus calleryana and submitted to chilling conditions during the dormancy period. Treatments were: (i) natural conditions; (ii) continuous artificial chilling; (iii) alternating temperatures, and (iv) total chilling privation. TSS and RS contents, as well as CWAI and SPS activities in tissues of branches that received insufficient chilling were lower than those that received sufficient chilling during winter. The starch concentration was superior in wood tissues of branches kept under chilling privation. The chilling privation disturbs carbohydrate mobilization in pear trees, reducing the sucrose synthesis capacity in wood tissues (source) and sucrose importation by the floral buds (sink).
\end{abstract}

Key words: Pyrus pyrifolia, carbohydrates, floral bud abortion, cell wall acid invertase, sucrose-phosphate synthase

\section{Introduction}

The southern region of Brazil has developed the cultivation of temperate fruit trees, especially apple (Malus domestica Borkh.), grape (Vitis vinifera L.), peach (Prunus persica (L.) Batsch) and plum (Prunus salicina Lindl.) cultures, but the pear (Pyrus sp.) culture did not show the same development, due to irregularity of the production and low yield of the orchards. Among the main limiting factors are: indefinition of the rootstocks, low rates of floral differentiation, high levels of flower bud abortion (variable with the cultivar, location and weather conditions) and lower percentage of fruit set (Nakasu et al., 1995).

In temperate-zone deciduous fruit trees, the most important factor in release dormancy is the accumulation of a certain amount of chilling (Lang, 1996). During dormancy, chilling temperature are associated with changes in carbohydrate contents and other substances, such as nucleic acids, proteins, polyamines, amino acids, organic acids and in the respiration rate, that may be related with bud break and the time of bloom (Wang and Faust, 1987).

Lack of chilling, associated with mild winter conditions, results in abnormal patterns of budbreak and development in temperate fruit trees (Mauget and Rageau, 1988) and is known as the main factor of pear flower bud abortion in Brazil (Petri et al., 2002; Petri and Herter, 2002) and New
Zealand (Klinac and Geddes, 1995; Do Oh and Klinac, 2003). Rakngan et al. (1996) observed that Japanese pear trees under enough chilling break dormancy earlier than plants with low chilling accumulation. The occurrence of intermittent hot days during dormancy period, with temperatures higher than $27^{\circ} \mathrm{C}$, delayed the release dormancy more than mild temperature fluctuations $\left(2\right.$ to $\left.3^{\circ} \mathrm{C}\right)$.

Carbohydrates are the main source of energy for the metabolic changes that occurred during the dormant release period. Carbohydrate availability is presumably of major relevance to the control of bud growth and development during dormancy and dormancy release (Sherson et al., 2003), and might be related to the bud necrosis (Cottignies, 1986). Sugar comes from starch accumulated in reserve tissues during the preceding summer is converted to sucrose during winter and the enzymes involved in this conversion are induced by the low temperatures. Chilling effect on the changes in starch and sugar concentrations may be explained because amylase activity is induced by cold temperature, increasing starch hydrolysis and, consequently, sugar concentration (Elle and Sauter, 2000).

During winter, starch degraded by amylases is used to the sucrose synthesis by the sucrose-6-phosphate synthase (SPS) in response to decreasing temperature. The sucrose produced in reserve tissue is transported by the xylem pathway to the bud and hydrolyzed to glucose and fructose to supply energy and carbonic precursors (Yoshioka et al., 1988). 
The SPS enzyme participates in the conversion of UDPglucose plus fructose into sucrose-6-P and plays an important role in the mobilization of glucidic reserves in plant tissues. A close connection was observed between the sucrose synthesis and the SPS activity in photosynthetic and nonphotosynthetic tissues of several fruit trees (Hubbard et al., 1991).

The cell wall acid invertase (CWAI) is associated with the sugars absorption and its activity determines the sink strength of a tissue, an organ or plant tissue. Hexoses (glucose and fructose) released by CWAI associated with the $\mathrm{H}^{+}$-hexose cotransporter of the transfer cells of the xylem, results in a regulatory mechanism capable of attracting more sucrose from the source tissue to the sink tissue (Godt and Roitsch, 1997).

One of the hypothesis to explain the pear bud necrosis problem is that the reserve mobilization and the carbohydrate fluxes to the buds are blocked when mild temperatures occurred during winter. The objective of this study was to compare the carbohydrate concentrations, the cell wall acid invertase and sucrose-phosphate synthase activities in wood of branches and floral buds of Japanese pear trees (Pyrus pyrifolia) cv. Housui, under different chilling conditions during the dormancy period.

\section{Materials and Methods}

This experiment was conducted in the winter period of 2007, under controlled conditions in Pelotas, state of Rio

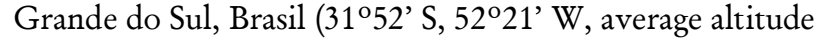
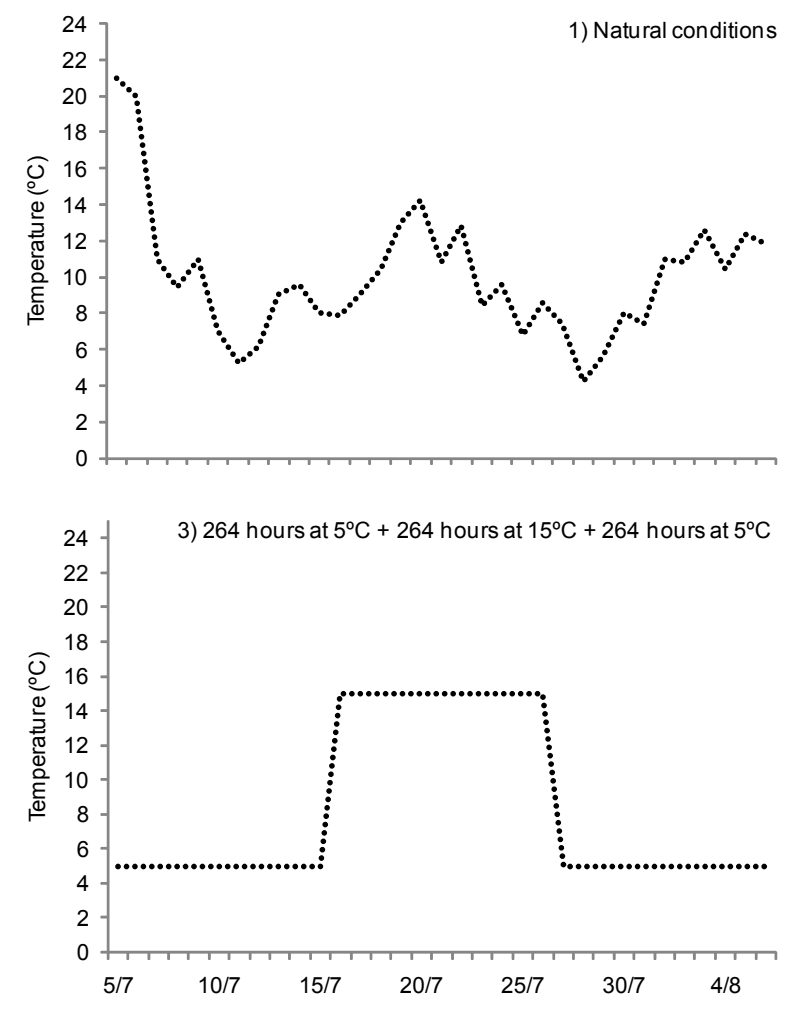

of $224 \mathrm{~m}$ ). The climatic classification of Pelotas is of type 'Cfa' (according to Köppen), temperate humid climate with hot summer. Annual averages are $1,582 \mathrm{~mm}$ of rainfall, $18.4^{\circ} \mathrm{C}$ of temperature, $78 \%$ of relative humidity and around $350 \mathrm{~h}\left(\leq 7.2^{\circ} \mathrm{C}\right)$ of natural chilling accumulation during the winter period.

The experimental material consisted of branches of Japanese pear trees cultivar Housui, collected from 16-year-old plants at the experimental orchard. The chilling requirement of 'Housui' is around 720 chilling hours $\left(\leq 7.2^{\circ} \mathrm{C}\right)$ and has shown high rates of floral bud abortion (close to $100 \%$ in most years) in southern Brazil (Faoro, 2001).

The collected branches were grafted on rootstocks of Pyrus calleryana in May 2007, kept in a greenhouse (around $25^{\circ} \mathrm{C}$ ) for 40 days until the start of treatment in June. Branches underwent the following treatments: T1) natural conditions: 235 hours $\left(\leq 7.2^{\circ} \mathrm{C}\right)$; T2) continuous artificial chilling: 792 hours (under $5^{\circ} \mathrm{C}$ ) in a cold room; T3) alternating temperatures: $264 \mathrm{~h}\left(5^{\circ} \mathrm{C}\right)$ in a cold room $+264 \mathrm{~h}\left(15^{\circ} \mathrm{C}\right)$ in a growth chamber $+264 \mathrm{~h}\left(5^{\circ} \mathrm{C}\right)$ in a cold room and $\left.\mathrm{T} 4\right)$ lack of chilling: $792 \mathrm{~h}\left(15^{\circ} \mathrm{C}\right)$ in a growth chamber (Figure 1). Upon completion of treatments, branches were transferred to the greenhouse $\left( \pm 25^{\circ} \mathrm{C}\right)$ to induce the budbreak. After three days, samples (wood and floral buds) were collected, frozen in liquid nitrogen, freeze dried and kept at $70^{\circ} \mathrm{C}$ until assayed. Evaluations were performed on threesample groups from 20 stems for each treatment.

A total of $200 \mathrm{mg}$ of dry matter for the quantification of carbohydrates was used. After grinding, the samples were
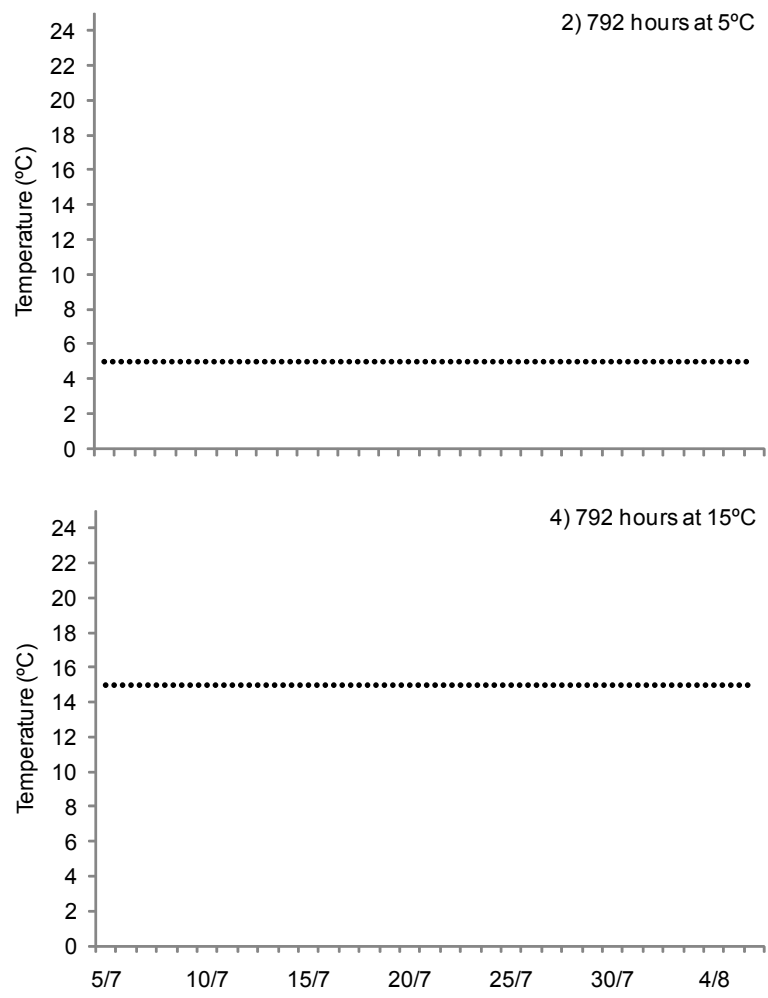

Figure 1 - Chilling treatments applied in grafted branches of Japanese pear cv. Housui. 
placed in test tubes, $5 \mathrm{~mL}$ of ethanol at $80 \%$ pre-heated $\left(80^{\circ} \mathrm{C}\right)$ were added, stirred and incubated at $85^{\circ} \mathrm{C}$ for $5 \mathrm{~min}$ in water bath. After centrifugation at $3,000 \times \mathrm{g}(6,000 \mathrm{rpm})$ for $10 \mathrm{~min}$, the supernatant was collected into volumetric flask of $50 \mathrm{~mL}$. The pellet was resuspended in $5 \mathrm{~mL}$ of ethanol at $80 \%$, pre-heated and centrifuged again, collecting the supernatant and add to the flask, completing the volume of the flask to $50 \mathrm{~mL}$ with distilled water. From this sample, an aliquot of $200 \mu \mathrm{L}$ of supernatant was used for quantification of total soluble sugars (TSS) by the anthrone method (Dische, 1962) in a spectrophotometer at $620 \mathrm{~nm}$ of wavelength $(\lambda)$. The quantification of reducing sugars (RS) was performed with aliquots of $750 \mu \mathrm{L}$ of supernatant by the dinitrosalicylic acid method (Miller, 1959) at $540 \mathrm{~nm}$ of wavelength $(\lambda)$. The TSS and RS concentrations were expressed in $\mathrm{mg} \mathrm{g}^{-1} \mathrm{DW}$ (dry weight) for both determinations.

For the starch quantification, the dry pellet was re-suspended in $3.33 \mathrm{~mL}$ of perchloric acid at $30 \%$ and stirred for $30 \mathrm{~min}$. Next, $6.67 \mathrm{~mL}$ of distilled water were added and was centrifuged at $3,000 \times \mathrm{g}(6,000 \mathrm{rpm})$ for $10 \mathrm{~min}$. The supernatant was collected into a volumetric flask of $50 \mathrm{~mL}$, repeating the same procedure again. Both supernatants were mixed and the volume of the flask was complete to $50 \mathrm{~mL}$ with distilled water. The starch quantification was carried out using $200 \mu \mathrm{L}$ of supernatant in $1 \mathrm{~mL}$ of distilled water. Then, it received $2 \mathrm{~mL}$ of anthrone $(0.1 \%)$ diluted in sulfuric acid p.a., and the test tubes were kept in ice bath (Dische, 1962). After, tubes were boiled for $3 \mathrm{~min}$ at $100^{\circ} \mathrm{C}$ and then cooled again in ice bath. The quantification was made at $620 \mathrm{~nm}$ $(\lambda)$, and the starch concentration expressed in $\mathrm{mg} \mathrm{g}^{-1} \mathrm{DW}$.

The enzyme extraction was performed by maceration of $150 \mathrm{mg}$ of tissue in liquid nitrogen. After grinding, $1200 \mu \mathrm{L}$ of $50 \mathrm{mmol} \mathrm{L}^{-1} \mathrm{HEPES} / \mathrm{KOH}$ buffer, $\mathrm{pH}$ 7.0, with $10 \mathrm{mM}$ DTT, $5 \mathrm{mM} \mathrm{MgCl}_{2}$, and $1 \mathrm{mM}$ EDTAwere added into Eppendorf tubes.

After well mixed, samples were centrifuged at 13,000 $\times \mathrm{g}$ $(18,900 \mathrm{rpm})$ for $15 \mathrm{~min}$ at $4^{\circ} \mathrm{C}$, and the supernatant was recovered to determine the activity of SPS (EC 2.4.1.14) according to the method of Schrader and Sauter (2002) and Hauch and Magel (1998). SPS activity was determined in non-limiting substratum conditions, in an incubation medium composed of $100 \mathrm{mM}$ HEPES/ $\mathrm{NaOH} \mathrm{pH}$ 7.5, 25 $\mathrm{mM} \mathrm{MgCl}, 25 \mathrm{mM}$ glucose-6-phosphate, $5 \mathrm{mM}$ fructose-6phosphate, and $20 \mathrm{mM}$ uridine diphosphate glucose (UDPglucose). UDPUDP is the product formed during the synthesis of sucrose and is measured indirectly by the nicotinamide adenine dinucleotide in reduced form (NADH) consumed by a multi-enzymatic reaction catalyzed by a complex of Pyruvate Kinase/Lactate Dehydrogenase (PK $450 \mathrm{U} / \mathrm{LDH}$ $450 \mathrm{U}$ ), using a of $100 \mathrm{mM}$ TRIS/HCl buffer, $\mathrm{pH} 7.5$, with $10 \mathrm{mM} \mathrm{MgCl}, 0.8 \mathrm{mM}$ phosphoenolpyruvate (PEP), and $0.3 \mathrm{mM} \mathrm{NADH}$. The reaction was developed for $40 \mathrm{~min}$ at $30^{\circ} \mathrm{C}$, being paralyzed by boiling at $100^{\circ} \mathrm{C}$ for $4 \mathrm{~min}$. Control samples were first boiled at $100^{\circ} \mathrm{C}$ for $4 \mathrm{~min}$. The absorbance was made in quartz cuvette at $340 \mathrm{~nm}(\lambda)$. The enzyme activity was expressed as nanomoles of NADH per minute per gram of fresh weight (nmol NADH min ${ }^{-1} \mathrm{~g}^{-1}$ $\mathrm{FW})$.
The CWAI extraction was performed by acid dialysis of the pellet resulting from the SPS enzyme extraction. This pellet was washed with $800 \mu \mathrm{L}$ of extraction buffer and centrifuged at $13,000 \times \mathrm{g}(18,900 \mathrm{rpm})$ for $5 \mathrm{~min}$, repeating the same procedure again. After this, it was resuspended in 500 $\mu \mathrm{L}$ of $70 \mathrm{mM} \mathrm{K}_{2} \mathrm{HPO}_{4} / 40 \mathrm{mM}$ Citrate buffer with $1 \mathrm{M}$ $\mathrm{NaCl} \mathrm{pH} \mathrm{5.0,} \mathrm{remaining} \mathrm{in} \mathrm{the} \mathrm{eppendorf} \mathrm{tubes} \mathrm{for} 18 \mathrm{~h}$ under refrigeration. Then, samples were centrifuged at 13,000 $\times \mathrm{g}(18,900 \mathrm{rpm})$ at $4^{\circ} \mathrm{C}$ for $15 \mathrm{~min}$, recovering the supernatant to determine the CWAI activity (EC 3.2.1.26) according to the method of Roitsch et al. (1995). The CWAI incubation medium was composed of a $70 \mathrm{mM} \mathrm{K}_{2} \mathrm{HPO}_{4} / 40 \mathrm{mM}$ Citrate 40 buffer, $\mathrm{pH} 5.0$ and $50 \mathrm{mM}$ sucrose. The reaction was developed during $30 \mathrm{~min}$ at $30^{\circ} \mathrm{C}$ and was stopped by boiling at $100^{\circ} \mathrm{C}$ for $5 \mathrm{~min}$. The control samples were first boiled for $5 \mathrm{~min}$ at $100^{\circ} \mathrm{C}$. Then, it was followed by the estimation of reducing sugars according to the methodology of Nelson (1944). The absorbance was performed at $520 \mathrm{~nm}$ $(\lambda)$ and the enzyme activity expressed in nanomoles of glucose produced per minute per gram of fresh weight (nmol $\min ^{-1} \mathrm{~g}^{-1} \mathrm{FW}$ ).

The experimental design was completely randomized with three replications in a double factorial scheme $(2 \times 4)$, with two levels of tissue factor (bud and wood) and four levels of chilling treatments factor (T1, T2, T3 and T4). Analysis of variance (ANOVA) was calculated and averages were grouped by Tukey test $(p \leq 0.05)$ using WinStat Program Software version 2.11 (Machado and Conceição, 2003).

\section{Results and discussion}

Interactions $(p \leq 0.05)$ between factors occurred to the total soluble sugars (TSS), reducing sugars (RS) and starch $\left(\mathrm{mg} \mathrm{g}^{-1} \mathrm{DW}\right)$ contents and to cell wall acid invertase (CWAI) and sucrose-phosphate synthase (SPS) activities (nmol min ${ }^{-1}$ $\mathrm{g}^{-1} \mathrm{FW}$ ) (Table 1). Concentrations of TSS, RS and starch were higher in the buds concerning the continuous (T2) and alternate artificial chilling (T3) compared to natural conditions (T1) and lack of chilling (T4) treatments. The reducing sugars were higher in both tissues of T2 treatment than in other treatments. The total soluble sugars concentrations were higher in wood tissues of T2 treatment and in bud tissues of T2 and T3 treatments. The accumulation of soluble sugars in the branches submitted to the cold occurred possibly due to the effect of low temperatures during the dormancy period, leading to a great accumulation of sugars in the buds exposed to chilling during the dormancy release phase (Figure 2).

The elevated RS (glucose and fructose) content in the tissues which receive more artificial chilling than others during dormancy enabled the 'resynthesis' of starch next to the floral buds tissues and provided more reserves to support the blossom and leafing processes. The starch mobilization from the reserve tissues (the stems and/or roots) to the growth areas (the meristems) of the woody plants, aims to increase the amount of soluble sugars potentially useful for cellular metabolism (Beck and Ziegler, 1989). Carbohydrates dynamics in tissues of temperate-zone deciduous fruit trees reflects the inter-conversion between starch and soluble sugars, since 
Table 1 -Summary of variance analysis for total soluble sugars (TSS), reducing sugars (RS), starch, cell wall acid invertase (CWAI) and sucrose-phosphate synthase (SPS) activities in 'Housui' pear tissues exposed to chilling treatments.

\begin{tabular}{lcrrrrr}
\hline \multirow{2}{*}{ Source of variation } & \multirow{2}{*}{ Degree of freedom } & \multicolumn{5}{c}{ Mean Square } \\
\cline { 3 - 6 } & & \multicolumn{1}{c}{ TSS } & \multicolumn{1}{c}{ RS } & \multicolumn{1}{c}{ Starch } & \multicolumn{1}{c}{ CWAI } & \multicolumn{1}{c}{ SPS } \\
\hline Tissue $(\mathrm{T})$ & 1 & $4220.60^{*}$ & $1586.18^{*}$ & $758.58^{*}$ & $92851.53^{*}$ & $97207.28^{*}$ \\
Chilling treatment $(\mathrm{C})$ & 3 & $1144.29 *$ & $59.75^{*}$ & $36.58^{*}$ & $60054.05^{*}$ & $21396.11^{*}$ \\
$\mathrm{~T} \times \mathrm{C}$ & 3 & $120.73^{*}$ & $24.26^{*}$ & $94.38^{*}$ & $31079.48^{*}$ & $5352.53^{*}$ \\
Error & 16 & 2.99 & 0.08 & 0.44 & 230.53 & 26.81 \\
\hline $\mathrm{CV}(\%)$ & & 2.76 & 2.27 & 3.49 & 8.92 & 4.64 \\
General mean & & 62.69 & 12.49 & 19.06 & 170.17 & 111.40 \\
\hline
\end{tabular}

*5\% probability level.
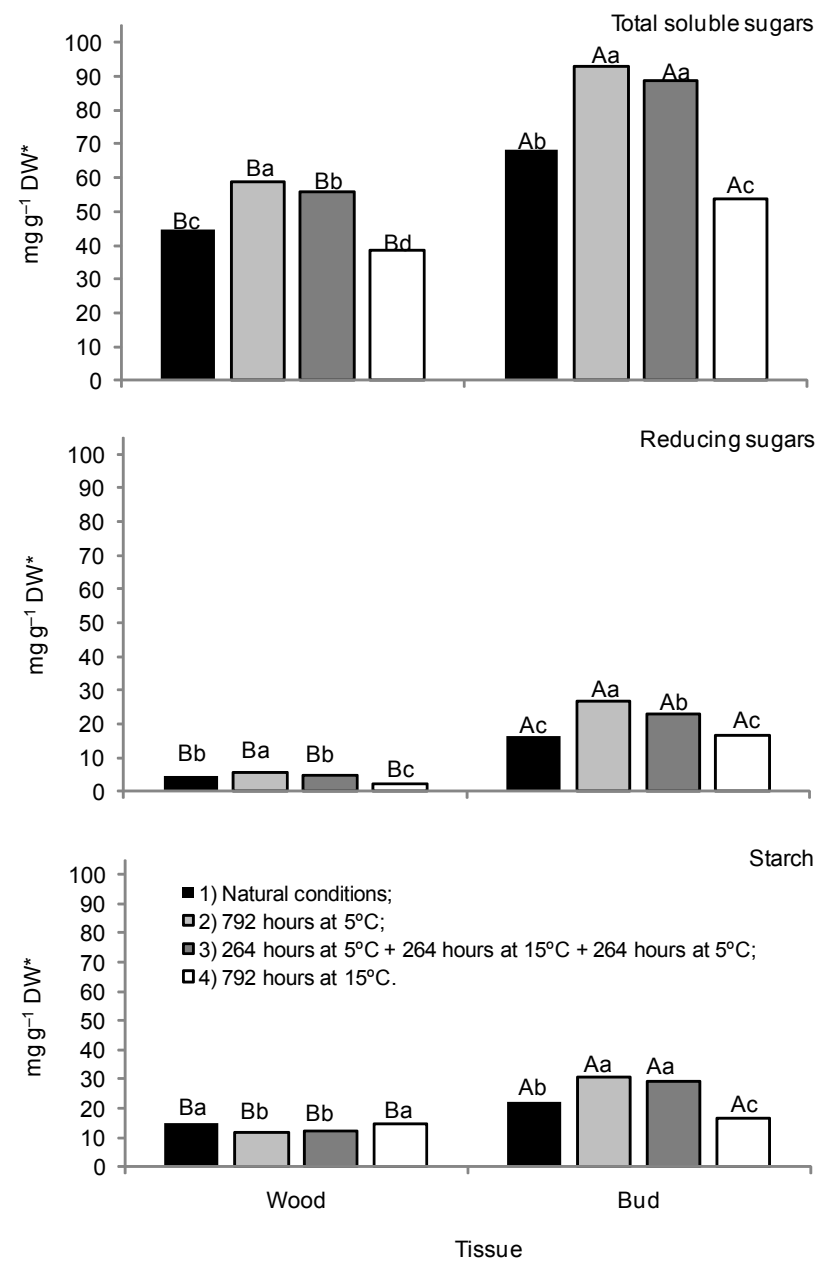

Figure 2 - Total soluble sugars, reducing sugars and starch in tissues of 'Housui' pears at budbreak induction after chilling treatments. Means with the same lowercase in the same tissue and means with the capital letters in the same chilling treatment do not differ (Tukey, $p \leq 0.05)$.

The increase in RS content in the buds that received cold may be associated with the decreased in starch content in reserve tissues to support the dormancy release processes (Maurel et al., 2004b; Bonhomme et al., 2005). According to these authors, the necrosis occurrence would be primarily a that starch hydrolyzed during dormancy period is temporally resynthesized before being used during dormancy release (Ameglio et al., 2004).

Starch concentration in the wood was higher under insufficient (T1) and deprived chilling (T4) than under chilled branches (T2 and T3). Probably, the starch concentration was lower in the wood tissue of chilled branches due to the induction of starchy enzymes by the low temperatures as observed in poplar trees (Populus sp.) by Sauter (1988). Unlike, the highest starch content in the wood of the branches under insufficient and deprived chilling could reflect the lack of induction of these starchy enzymes during the dormancy period, as also observed by Citadin et al. (2009) in wood tissues of walnut trees. Sauter et al. (1998) found a high correlation between the low temperature, the starch degradation and the increasing in the content of sugars in Populus stems. The nature of the sugars released after exposure of the shoots to cold showed that it was essentially the alpha-amylase enzyme responsible for starch hydrolysis at low temperatures. The contact of this enzyme with the starch granules increased strongly and linearly with decreasing temperature in the xylem parenchyma cells during the dormancy period.

The uptake of nutrients by the meristematic zone could depend on the capacity of transportation from the reserve domain (wood and/or root) to the growth area (meristems). During dormancy, the bud exhibited low sugar absorption potential and increased the hexose concentration by starch hydrolysis. However, after dormancy release, the buds become high sink tissues, increasing the soluble sugars importation, by active transport, which are metabolized to provide energy and carbon storage (Marquat et al., 1999).

In our study, branches submitted to insufficient chilling had higher contents of starch in wood and low RS content in bud tissues. Leite et al. (2004) found that peach branches kept under natural conditions, with their complete chilling requirement satisfied, showed increases in the RS and starch contents in bud tissues. Unlike, in plants kept under chilling privation (insufficient chilling), the carbohydrates accumulation in the buds was not sufficient to allow their normal development. Lacointe et al. (1993) observed that the starch and soluble sugars concentrations follow a reverse pattern during dormancy, suggesting that a process of interconversion occurs between them. 
consequence of the floral bud incapacity to metabolize the available sucrose and/or sorbitol to provide the required hexoses during the blossom and leafing phases. Bonhomme et al. (2010) measured the bud capacity of walnut (Juglans regia) to use the xylem sap carbohydrates during the rest period until bud break, observed that the bud uptake capacity varies according to the temperature. The flow rates between xylem vessels and buds increased 1 month before bud break, when buds were able to import high sugar quantities (around $2000 \mu \mathrm{g}$ of sucrose $\mathrm{h}^{-1} \mathrm{~g}^{-1} \mathrm{DW}$ ). Bonhomme et al. (2010) also showed a close correlation between influx of soluble sugars and the concomitant DW increase in buds.

In chilled branches (T2 and T3) the activities of SPS in both tissues and CWAI in the bud tissue were higher than in the other treatments, which received insufficient (T1) or were deprived of chilling (T4). The increases in RS and starch contents in buds and in the TSS content in the wood of the chilled branches are probably related to the increases in the activities of CWAI in buds and SPS in the wood, respectively (Figure 3).

The continuous chilling treatment (T2) was more effective to convert starch into sucrose in wood and more effective in the hydrolysis of this sucrose into reducing sugars in
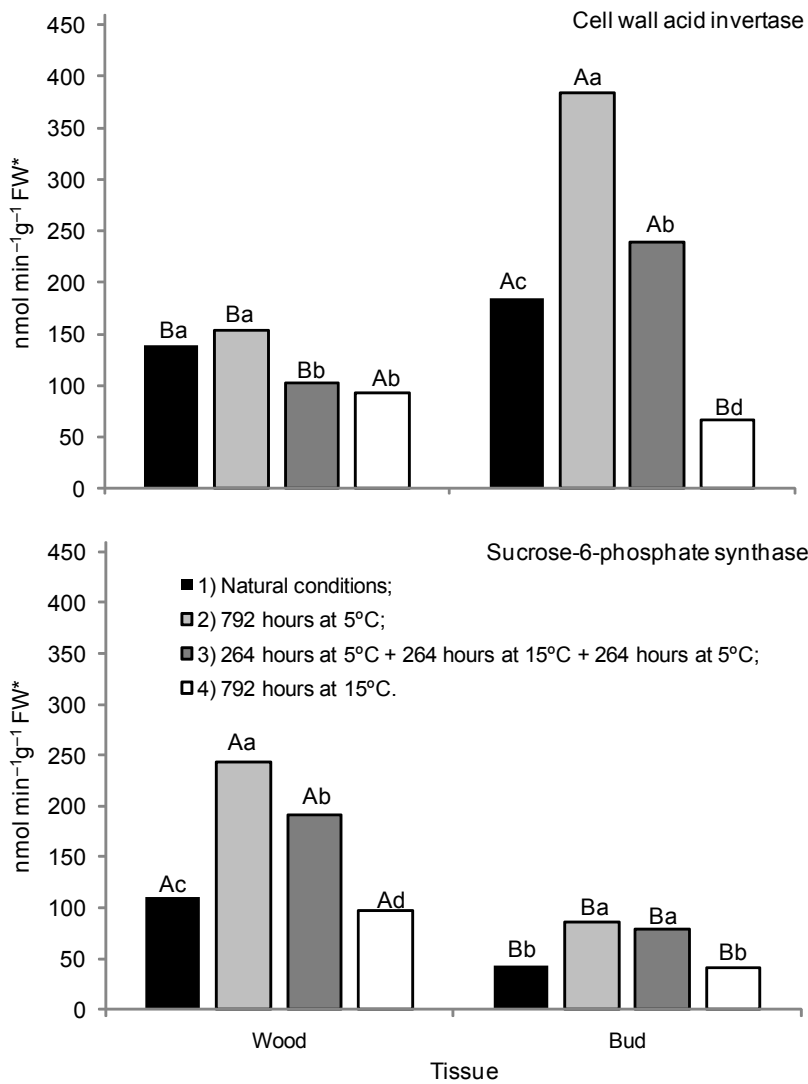

Figure 3 - Cell wall acid invertase and sucrose-6-phosphate synthase activities in tissues of 'Housui' pears at budbreak induction after chilling treatments. Pelotas, Rio Grande do Sul, Brazil, 2007. Means with same lowercase in the same tissue and means with the same capital letters in the same chilling treatment do not differ (Tukey, $p \leq 0.05)$. buds than all the other treatments. Activities of CWAI in the buds and of SPS in the wood tissues were higher in branches submitted to continuous cold than in other treatments and possibly has increased the amount of sucrose that reached the buds and was hydrolyzed in glucose and fructose. CWAI activity may be inversely correlated to the sucrose concentration and positively correlated with the glucose and fructose concentrations in the sink tissues (Ito et al., 2002). Maurel et al. (2004a) found an increase in CWAI activity in peach buds just before the leafing in natural conditions, but when branches were maintained under chilling privation this activity remained low.

During winter, starch degraded in the wood tissue, by the action of amylases induced by cold, is metabolized into sucrose by the enzyme SPS, which exports sugar to the buds, where it is hydrolyzed into glucose and fructose by CWAI or sucrose synthase (SuSy) for the supply of energy and carbonaceous precursors (Yoshioka et al., 1988). The low SPS activity observed in the wood tissues of insufficient (T1) and lack of chilling (T4) treatments demonstrates its limited ability to export sucrose under these circumstances. Likewise, in the same treatments, a low activity of CWAI in the buds was observed, which characterizes the low import capacity of sucrose. Thus, these low SPS and CWAI activities together characterizes a weak capacity to mobilize reserves from the source (wood) to the sink tissue (floral bud), causing a blockage in the bud growth and development vital processes and, consequently, the possible flower bud necrosis.

The high temperatures during dormancy nullify chilling accumulation in Japanese pear trees, which disturb carbohydrate mobilization from the reserve tissues and the absorption of sugars by the buds (Honjo et al., 2002). The intensification of flower bud abortion may be related to the lack of chilling and to the temperature fluctuations during the dormancy period. The necrosis symptoms became more intense during winter period, proportionally to the increasing temperatures, affecting most of plants at end of dormancy (Marafon et al., 2010).

In branches subject to sufficient chilling accumulation, the capacity of synthesis and exportation of sucrose from the apoplast becomes larger after dormancy release and coincides with the increase of starch enzyme activity. The starch stored in xylem parenchyma cells is converted rapidly to sugars, particularly sucrose, and is then secreted by contact xylem cells into the xylem vessels. Sucrose is transported along the xylem pathway together with the water, to the buds, where it is directly absorbed or further hydrolyzed in the apoplast, contributing to their import. Temperature may determine whether parenchyma secrete or absorb sugars, with secretion dominating at low temperatures (Ameglio et al., 2004). Schrader and Sauter (2002) found out that the SPS activity in the xylem parenchyma of the branches of Populus, Salix, Acer and Fagus increases in late autumn, is maximum in the winter (during the starch conversion into soluble sugars), and decreases in early spring, during the starch resynthesis in the adjacent tissues to the buds. These authors found that the SPS activity in branches kept at $0^{\circ} \mathrm{C}$ during dormancy was higher than those kept at $10^{\circ} \mathrm{C}$. 
Hauch and Magel (1998) stated that the reduction in starch content in the cells of the xylem parenchyma, in Robinia branches, is associated with increased SPS activity during winter, indicating the conversion of starch into sucrose. When sucrose is translocated to non-photosynthetic tissues, it is rapidly converted into fructose and glucose by invertase enzymes. In these organs, fructose and glucose may be used in three ways: i) in the respiration, for Adenosine Tri-Phosphate (ATP) formation and other important compounds; ii) be stored in the vacuole for later use, and iii) glucose, that may be converted into starch serving as a energetic reserve for use in other circumstances. Therefore, the lower activity of SPS in the branches with insufficient or lack of chilling accumulation can be interpreted as a lower ability to export sucrose and the lower activity of CWAI can be a consequence of the low quantity of sucrose in the xylem parenchyma vessels of Japanese pears. This low capacity to import sugar, water and other nutrients of the bud tissues caused by high temperatures during winter, lead to the exhaustion of carbohydrate reserves and could be the cause the flower bud abortion.

\section{Conclusions}

The exposure of branches at low temperature affected starch and soluble sugar contents and sucrose-metabolizing enzymes activities in wood and buds tissues of Japanese pears. While starch content decreases in wood, RS content increases in bud tissues of chilled branches. Unlike, starch content remained high in wood tissues and the RS content does not increase in those branches kept under chilling privation.

The chilling privation disturbs carbohydrate mobilization in pear trees, reducing the sucrose synthesis capacity in wood tissues and the sucrose importation by the floral buds. Therefore, the sufficient chilling supply during the dormancy period increases the cell wall acid invertase and sucrose-6phosphate synthase activities providing increases in the reducing sugars and starch contents in bud tissues that are used to budburst and blooming in the spring.

\section{Acknowledgements}

To Embrapa Clima Temperado, Universidade Federal de Pelotas, CAPES and CNPq by the provision of financial support and by the infrastructure resources.

\section{References}

Ameglio, T.; Decourteix, M.; Alves, G.; Guilliot, A.; Julien, J.L.; Lacointe, A.; Pétel, G.; Sakr, S.; Valentin, V. 2004. Temperature effects on xylem sap osmolarity in walnut trees: evidence for a vitalistic model of winter embolism. Tree Physiology 24: 785-793.

Beck, E.; Ziegler, P. 1989. Biosynthesis and degradation of starch in higher plants. Annual Review of Plant Physiology and Plant Molecular Biology 40: 95-117.

Bonhomme, M.; Peuch, M.; Ameglio, T.; Rageau, R.; Guilliot, A.; Decourteix, M.; Alves, G.; Sakr, M.; Lacointe, A. 2010. Carbohydrate uptake from xylem vessels and its distribution among stem tissues and buds in walnut (Juglans regia). Tree Physiology 30: 89-102.
Bonhomme, M.; Rageau, R.; Lacointe, A; Gendraud, M. 2005. Influences of cold deprivation during dormancy on carbohydrate contents of vegetative and floral primordia and nearby structures of peach buds (Prunus persica L. Batch). Scientia Horticulturae 105: 223-240.

Citadin, I.; Guilliot, A.; Bonhomme, M.; Rageau, R. 2009. Walnut enzyme activity related with carbohydrate mobilization during dormancy period. Revista Brasileira de Fruticultura 31: 305-313. (in Portuguese, with abstract in English).

Cottignies, A. 1986. The hydrolysis of starch as related to the interruption of dormancy in the ash bud. Journal of Plant Physiology 123: 381-388.

Dische, Z. 1962. General colors reactions. p. 477-520. In: Whistler, R.L.; Wolfram, M.L. Carbohydrate chemistry. Academic Press, New York, NY, USA.

Do Oh, S.; Klinac, D. 2003. Relationship between incidence of floral bud death and temperature fluctuation during winter in Japanese Pear (Pyrus pyrifolia) cv. Housui under New Zealand climate conditions. Journal of Korean Society for the Horticultural Science 44: 162-166.

Elle, D.; Sauter, J.J. 2000. Seasonal changes of activity of a starch granule bound endoamylase and a starch phosphorylase in poplar wood (Populus $x$ Canadensis Moench 'robusta') and their possible regulation by temperature and phytohormones. Journal of Plant Physiology 156: 731-740.

Faoro, I.D. 2001. Morphology and physiology. p. 67-94. In: Empresa Catarinense de Pesquisa Agropecuária [EPAGRI]. Nashi, the Japanese pear. Florianópolis, SC, Brazil. (in Portuguese).

Godt, D.E.; Roitsch, T. 1997. Regulation and tissue-specific distribution of mRNAs for three extracellular invertase isoenzymes of Tomato suggests an important function in establishing and maintaining sink metabolism. Plant Physiology 115: 273-282.

Hauch, S.; Magel, E. 1998. Extractable activities and protein content of sucrose-phosphate synthase, sucrose synthase and neutral invertase in trunk tissues of Robinia psendoacacia L. are related to cambial wood production and heartwood formation. Planta 207: 266-274.

Honjo, H.; Kobayashi, M.; Watanabe, M.; Fukui, R. 2002. Effect of intermittent periods on bud break and carbohydrate content of Japanese pear (Pyrus pyrifolia Nakai) in different endodormancy stages. Acta Horticulturae 587: 397-403.

Hubbard, N.L.O.; Pharr, M.D.O.; Huber, S.C. 1991. Sucrose phosphate synthase and other sucrose metabolizing enzymes in fruits of various species. Physiologia Plantarum 82: 191-196.

Ito, A; Hayama, H.; Kashimura, Y. 2002. Sugar metabolism in buds during flower bud formation: comparison of two Japanese pear [Pyrus pyrifolia Nak.] cultivars possessing different flowering habits. Scientia Horticulturae 96: 163-175.

Klinac, D.C.; Geddes, B. 1995. Incidence and severity of the floral 'budjump' on nashi grown in the Waikato region of New Zealand. New Zealand Journal of Crop and Horticultural Science 23: 185190.

Lacointe, A., Kajji, A., Daudet, F.A., Archer, P., Frossard, J.S. 1993. Mobilization of carbon reserves in young walnut trees. Acta Botanica Gallica 140:435-441.

Lang, G.A. 1996. Plant Dormancy: Physiology, Biochemistry and Molecular Biology, CAB International, Wallingford, UK.

Leite, G.B.; Bonhomme, M.; Guilliot, A.; Sakr, S.; Lacointe, A.; Pétel, G.; Rageau, R.; Maurel, K.; Rodriguez, A.C. 2004. Influence of lack of chilling on bud-break patterns and evolution of sugar contents in buds and stem tissues along the one-years-old shoot. Acta Horticulturae 662: 61-69.

Machado, A.A.; Conceição, A.R. 2003. WinStat: Statistical Analysis System for Windows; Version 2.11. Universidade Federal de Pelotas, Pelotas, RS, Brazil. (in Portuguese).

Marafon, A.C.; Hawerroth, F.J.; Herter, F.G. 2010. Occurrence and intensity of floral bud necrosis on Japanese pear cv. Housui during the winter period. Agropecuária Catarinense 23: 64-69. (in Portuguese, with abstract in English). 
Marquat, C.; Vandamme, M.; Gendraud, M.; Petel, G. 1999. Dormancy in vegetative buds of peach: relation between carbohydrate absorption potentials and carbohydrate concentration in the bud during dormancy and its release. Scientia Horticulturae 79:151162.

Mauget, J.C.; Rageau, R. 1988. Bud dormancy and adaptation of apple tree to mild winter climates. Acta Horticulturae 232:101-108.

Maurel, K.; Leite, G.B.; Bonhomme, M.; Guilliot, A.; Regeau, R.; Pétel, G.; Sakr, S. 2004a. Trofic control of bud break in peach trees (Prunus persica): a possible role of hexoses. Tree Physiology 24: 579-588.

Maurel, K.; Sakr, S.; Gerbe, F.; Guilliot, A.; Bonhomme, M.; Rageau, R.; Petel, G. 2004b. Sorbitol uptake is regulated by glucose through hexokinase pathway in vegetative peach tree bud. Journal of Experimental Botany 55: 879-888.

Miller, G.L. 1959. Use of dinitrosalicylic acid reagent for determination of reducing sugar. Analytical Chemistry 31: 426-427.

Nakasu, B.H.; Herter, F.G.; Leite, D.L.; Raseira, M.C.B. 1995. Pear flower bud abortion in southern Brazil. Acta Horticulturae 395: 185-192.

Nelson, N. 1944. A photometric adaptation of the Somogyi method for the determination of glucose. Journal of Biological Chemistry 153: 375-379.

Petri, J. L.; Herter, F.G. 2002. Nashi pear (Pyrus pyrifolia) dormancy under mild temperate climate conditions. Acta Horticulturae 587: 353-361.

Petri, J.L.; Leite, G.B.; Yasunobu, Y. 2002. Studies on causes of floral abortion in Japanese pear (Pyris pyrifolia Nakai) in southern Brazil. Acta Horticulturae 587: 375-380.

Rakngan, J.; Gemma, H.; Iwahori, S. 1996. Phenology and carbohydrate metabolism of Japanese pear trees grown under continuously high temperatures. Journal of the Japanese Society for Horticultural Science 65: 55-65.
Roitsch, T.; Bittner, M.; Godt, D.E. 1995. Induction of apoplastic invertase of Chenopodium rubrum by D-glucose and a glucose analog and tissue-specific expression suggest a role in sink-source regulation. Plant Physiology 108: 285-294.

Sauter, J.J. 1988. Temperature induced changes in starch and sugars in the stem of Populus x Canadensis "robusta". Journal of Plant Physiology 132: 608-612.

Sauter, J.J.; Elle, D.; Witt, W. 1998. A starch granule bound endoamylase and its possible role during cold acclimation of parenchyma cells in poplar wood (Populus x canadensis Moench robusta). Journal of Plant Physiology 153: 739-744.

Schrader, S.; Sauter, J.J. 2002. Seasonal changes of sucrose-phosphate synthase and sucrose synthase activities in poplar wood (Populus $\mathrm{X}$ canadensis Moench) and their possible role in carbohydrate metabolism. Journal of Plant Physiology 159: 833-843.

Sherson, S.M.; Alford, H.L.; Forbes, S.M.; Wallace, G.; Smith, S.M. 2003. Roles of cell wall invertases and monosaccharide transporters in the growth and development of Arabidopsis. Journal of Experimental Botany 54: 525-531.

Wang, S.Y.; Faust, M. 1987. Metabolic activities during dormancy and blooming of deciduous fruit trees. Israel Journal of Botany 37: 227-243.

Yoshioka, H.; Nagal, K.; Aoba, K.; Fukumoto, M. 1988. Seasonal changes of carbohydrates metabolism in apple trees. Scientia Horticulturae 36: 219-227.

Received March 18, 2010

Accepted October 15, 2010 